\title{
Geç Dönem Osmanlı Modernleşmesine Genel Bir Bakış
}

\author{
Rüya Telli* \& Ayşenur Yılmaz*
}

\section{Öz}

Bu yazıda, Osmanlı modernleşmesinin on dokuzuncu ve yirminci yüzyıllar boyunca temel çelişkileri ve belirleyici çatışma alanları konu edilmektedir. Osmanlı modernleşmesi kavramı imparatorluğun geri kaldığı kabulüyle çok yönlü yenilik çabalarına işaret eder. Yaklaşık iki yüz yıl boyunca devam eden bu süreç, Osmanlı için devleti kurtarmak amacıyla biçimlenmiştir. Dolayısıyla, geç dönem Osmanlı modernleşmesi, Batı'ya askeri ve bürokratik açıdan yetişme kaygısıyla farklı toplumsal, ekonomik ve siyasi dinamiklerin yarattığı doğal ikilemlerle boğuşarak gelişme göstermiştir. Bu bağlamda, makale boyunca Batı'ın içerisinde bulunduğu özgün koşulların bir ürünü olarak modernleşme olgusunun, "doğulu” olan Osmanlı için ne anlama geldiği ve nasıl gerçekleştiği açıklanmaya çalışılacaktır.

Anahtar Kelimeler: Osmanlı İmparatorluğu, Batı, Modernleşme, Batılılaşma, Reform.

\section{An Overview of The Late Ottoman Modernisation}

\section{Abstract}

In this article, the main contradictions and decisive conflict areas of the Ottoman modernisation throughout the nineteenth and twentieth centuries are discussed. The concept of Ottoman modernisation points to multi-faceted innovation efforts with the acceptance that the empire is left behind. This process, which continued for nearly two hundred years, was shaped with the aim of saving the state for the Ottomans. Therefore, the modernisation of the late Ottoman period has developed by struggling with natural dilemmas created by different social, economic and political dynamics with the concern of catching up the West with the military and bureaucracy. In this context, throughout the article, it will be tried to explain what the concept of modernisation as a product of the original conditions of the West is and how it happened for the Ottoman.

Keywords: Ottoman Empire, West, Modernisation, Westernisation, Reform.

*Doktora Öğrencisi | İstanbul Üniversitesi, Siyasal Bilgiler Fakültesi | ruya.telli@gmail.com ORCID: 0000-0002-4576-0842 | DOI: 10.36484/liberal.784116

**Doktora Öğrencisi | İstanbul Üniversitesi, Siyasal Bilgiler Fakültesi | ylmzaysenur001@gmail.com ORCID: 0000-0003-0360-9156 | DOI: 10.36484/liberal.784116

Liberal Düšünce Dergisi, Yıl: 25, Sayı: 100, Güz 2020, ss.9-35.

Gönderim Tarihi: 22 Ağustos 2020 | Kabul Tarihi: 2 Aralık 2020 


\section{Giriş}

Modernleşme kavramı, sosyo-ekonomik ve siyasal bir süreç olarak toplumların değişim ve dönüşümünü ifade eder. Modernleşme, Batı Avrupa'da Aydınlanma düşüncesi, Fransız Devrimi ve sanayileşme gibi tarihsel olayların etkileşimiyle ortaya çıkarken, Osmanlı'da kendi iç dinamiklerinin ve dış faktörlerin etkileşimiyle kendine özgü süreç olarak gelişmiştir. Osmanlı’nın geç döneminde başlayan modernleşme süreci, Cumhuriyet'in ilanı ile ulus-devlet olmanın eklendiği bir biçime bürünerek devam etmiştir. Bu nedenle, makalenin giriş kısmında modernleşme kavramsal açıdan ele alınacak ve sonrasında Osmanlı-Türk modernleşmesine ilişkin kuramsal yaklaşımlara değinilecektir. Modernleşmeye ilişkin farklı yaklaşımlardan kısaca bahsedilmesinin nedeni Osmanlı-Türk modernleşmesine ilişkin zengin bir kuramsal katkının var olduğunun gösterilmek istenmesidir. Ancak çalışma kuramsal bir tartı̧̧ma zemininde değil, tarihsel süreçte değişim ve dönüşümün seyrini takip etmek şeklinde kurgulanmıştır. Temel amacı “devleti kurtarmak" olan Osmanlı modernleşmesinin tek bir kuram çerçevesinde ya da tek bir konu üzerinden ele alınması mümkündür; ancak bu makalenin amacı bir konu ya da kurama odaklanmak şeklinde değil geç dönem Osmanlı modernleşmesinin genel çerçevesini çizmek ve bu bütünsellik içinde modernleşme sürecinin kendine özgü yanlarıyla nasıl ilerlediğini tartışmaktır. Bu minvalde modernliği, çok boyutlu ve çok zamanlı bir siyasal ve toplumsal oluş hali olarak ele alan makalede, geç dönem Osmanlı modernleşme sürecinde yaşanan gelişmeler süreklilik ve kopukluklar bağlamında değerlendirilmektedir. Makalede tek bir "gerçeklik" ya da tek bir "doğru” yu ön plana çıkaran pozitivist anlayış yerine, olay ve olgulara ilişkin çoklu gerçeklikleri farklı bakış açıları temelinde ele alan yorumlayıcı yaklaşım esas alınmıştır. Bu bakımdan mirası erken dönem Cumhuriyet'e devrolan geç dönem Osmanlı modernleşmesinin içinde barındırdığı çelişki ve çatışmalarla birlikte, toplumsal, siyasal ve ekonomik açılardan değişim ve dönüşüm getiren bir inşa olduğu fikri savunulmaktadır. Çalışmada, anayasal yönetime kapı araladığı için geç Osmanlı tarihi açısından kırılma noktası olan 1876 tarihi esas alınarak I. Meşrutiyet'in ilanına kadar olan dönem öncesi ve I. Meşrutiyet sonrası olmak üzere iki bölümden oluşan tarihsel bir seyir içinde analiz yapılmaktadır.

\section{Modernleşme Kavramı}

Modernleşme, "gelişmemiş ülkeler daha ileri ve karmaşık toplumsal ve siyasal örgütlenme kalıplarına doğru geçerlerken meydana gelen ekonomik, toplumsal ve kültürel değişme süreci” olarak tanımlanır (Outwaite, 2008: 506). 
Kavrama orijinal anlamını veren ve kökeni itibarıyla Latince bir sözcük olan modernus, paganizmin inkârı ve Hristiyanlığın başlangıcını ifade eder. İçerikleri değişse de 'modern' terimi eskiden yeniye geçişin sonucu anlamında, antik çağla kendisi arasında ilişki kuran dönemlerin bilincidir (Habermas, 1994: 31) Modernlik, ekonomik, politik ve kültürel açılardan değişim ve dönüşümle birlikte yeni tipte bir toplumun ortaya çıktığı karmaşık bir süreçtir (Swingewood, 1998: 9).

Fransız Devrimi ve Sanayi Devrimi'nin eş zamanlı olarak gerçekleşmesinin ardından on dokuzuncu yüzyılda Avrupa'da meydana gelen siyasi, toplumsal, ekonomik dönüşümlerin 'ilerleme’ aşamalarında öncü hale gelmesi ve Batı'nın, Batı dışı toplumlar tarafından model olarak kabul görmeye başlaması ile modernleşmek, Batılılaşmakla eş anlamlı olarak kullanılmaya başlamıştır. Terminolojik açıklamanın açık biçimde işaret ettiği üzere modernleşmek, yalnızca Batı dışı dünyanın tecrübe edebileceği bir durumdur. Modernleşme bir sürece işaret ederken, Batılılaşma kavramı sınırları belli bir mekânı imler. Göçek, çoğu zaman birbirinin yerine kullanılan Batılılaşma ve modernleşme kavramlarına ilişkin zamansal ve mekânsal ayrım çizer. Batılılaşma on sekizinci ve on dokuzuncu yüzyıllarda hâkim bir kavramken, esasında yirminci yüzyıldaki modernleşme kavramının önünü açar. Batılı toplumlar ile diğer toplumlar arasındaki ilişkiyi imleyen Batılılaşma, yerini küresel bir içerik taşıyan modernleşmeye bırakır. On sekizinci yüzyılda Avrupa'nın yaşadığı politik ve ekonomik dönüşüm, Batı'ya özgü olmaktan çıkarak evrensel bir deneyim haline gelir. Bu süreçte "modernleşme" terimi "Batılılaşma" teriminin yerine geçerek yaygın bir şekilde kullanılmaya başlar (Göçek, 1999: 17-18).

Çağımızın önemli sosyologlarından Anthony Giddens, modernleşmeyi on yedinci yüzyılda Avrupa'da başlayıp tüm dünyaya yayılan toplumsal yaşam ve örgütlenme biçimlerinin değişmesiyle sonuçlanan bir süreç olarak ele alır (Giddens, 1994: 9). Modernleşmenin bir süreç olarak ele alınmasının nedeni, modern olan ile geleneksel olanın sınırlarını net olarak belirlemek ya da toplumların ne zaman "modern" sıfatını taşımaya başladığını keskin bir şekilde belirtmenin mümkün olmamasıdır. Giddens bu gerekliliğe şu şekilde dikkat çeker (1994: 12): “Geleneksel ile modern arasında süreklilikler vardır ve bunlar birbirinden tamamen ayrı parçalar değildir...” Böylece modernleşmenin geleneksel toplumdan modern topluma geçiş süreci olduğu ancak modernleşirken hangi politikalar yürütüleceği, hangi yönde ilerleneceği ve modern olanın ne olduğu soruları önem kazanır.

Bauman ise modernliğin tarihini ilerlemenin tarihi olarak ele alırken, moderniteyi şöyle tarif eder (Bauman, 2000: 20): “Batı Avrupa'da, on yedinci 
yüzyıldaki bir dizi derin toplumsal, yapısal ve entelektüel dönüşümle başlayan; Aydınlanmanın gelişmesiyle kültürel bir proje olarak, kapitalist ve daha sonra da komünist endüstri toplumunun gelişmesiyle de toplumsal olarak kurulan bir yaşam biçimi olarak olgunluğa erişen tarihsel bir dönemdir." Bauman'ın geliştirdiği tanımdan hareketle modern olanın Batı'da ortaya çıkan bir tarihsel süreç olduğu, kapitalist ve ileri toplumların toplumsal, siyasal ve entelektüel dönüşümünün modernleşme olarak tanımlandığı sonucuna varılabilir. Kavramsal açıdan modernleşme, birçok farklı tanımlamalarla yer bulur. Bu tanımlamaların ortak yanı bir olgu olarak modernleşmenin, tek bir tarihsel olay yerine birbiriyle ilişkili tarihsel olayların etkisiyle oluşan ve topyekûn değişim ve dönüşüm getiren karmaşık bir süreç olduğudur.

Modernleşme kavramsal olarak sıklıkla tartışılan bir konu iken, tartışmalar 1960 sonrası yeni bir boyut kazanır ve kuramsal bir çerçevede ele alınmaya başlanır. On dokuzuncu yüzyıl klasik sosyologları tarafından toplumsal değişim ve dönüşüm başlıkları altında tartışılan modernleşme, 1960'lı yıllarda davranışçı gelenek ve pozitivizm çizgisinde kuramsallaştırılmış, temelini ise klasik sosyologların toplumsal değişim ve dönüşüm tartışmaları oluşturmuştur. Auguste Comte tarafından metafizik-pozitif toplum; Ferdinand Tönnies tarafindan cemaat-cemiyet; Max Weber tarafından geleneksel-modern (rasyonalist) toplum; Emile Durkheim tarafından mekanik-organik toplum; Karl Marx feodal-kapitalist toplum kavramları üzerinden yapmış oldukları tartışmalar modernleşme tartışmalarının başlangıcı olarak görülebilir. Toplumların tarihsel ilerlemeleri ve 'bugünün' dünden farkını ortaya koyarken içinde bulundukları yüzyılda Avrupa’nın dünyadaki merkezi rolü göz önünde bulundurularak yapılan tartışmalar, Batı'da var olan şeyin 'ideal tip' olarak görülmesiyle sonuçlanmıştır. Batı'da üretilen tartışmalar, Batı'da olanın bilimsel olan şeklinde etiketlenmesini beraberinde getirirken, Batılı olmayan toplumların bilimselleşme ve kurumsallaşma süreçleri de Batılılaşmak şeklinde algilanmıştır. Böylece, on dokuzuncu yüzyıldan itibaren modernleşme kavramı ve modernleşme süreci, Batı dışı dünya için kullanılan ve Batı dışı dünyanın gerçekleştirmesi gereken bir süreç olarak görülmeye başlamıştır: Batı'da olan modern olandır ve dünyanın geri kalanının modernleşmeye ihtiyacı vardır.

Modern olan nedir, modern toplum nasıl olmalıdır, modern devlet şekli hangisidir, modern yönetim şekli hangisidir, hangi rejimler modern olarak kabul edilebilir gibi çeşitli sorular üzerinden tartışmalar yürütülürken, modernleşme kuramı, Batı dışı toplumlara Batılılaşmaları gerekliliğini bilimsel bir açılama olarak sunar. Kuram, toplumları geleneksel ve modern olmak üzere iki kutuplu bir eksen üzerinde sıraya dizerken, toplamların hepsinin, zaman içerisinde bu eksen üzerinde üst noktaya geleceği, dolayısıyla 
her ülkenin aynı yollardan geçerek -Batı ile aynı olan yollardan- az gelişmişlikten gelişmişliğe doğru yol alacağı yönünde tek boyutlu bir gelişme modelini öngörmektedir (Kansu, 2009: 14). Bahsi geçen iki kutuplu sistemin modern ucunda yer alan ülkeler, sanayileşmiş-demokratik modern Batı ülkeleridir. Diğer ülkeler ise, ilerleme kuramı gereği, benzer aşamalardan geçerek modernleşebilecektir. Bu minvalde modernleşmek, evrimci bir süreçtir ve Batı'dan farklı bir modelle modernleşmek ya da gelişmek, kurama göre mümkün değildir. Modernleşme kuramı davranışçı gelenek ve pozitivizm içerisinde gelişir. Niceliksel ve ampirik bilim anlayışı çerçevesinde ilerleyen kuramın, amaca yönelik tartışmaların bir yansıması olduğunu iddia etmek mümkündür. Amaç, geleneksel devletleri Batı modeline uygun devletler haline getirmek için uygun görülebilir. Bu minvalde eski sömürgeler, İkinci Dünya Savaşı sonrasında bağımsız devletler haline dönüşürken yeni kurulacak devletlerin veya var olan üçüncü dünya ülkelerinin, Sovyet modeline göre değil Batı modeline uygun gelişmesi amaçlanmaktadır. Kansu, 1960 sonrası modernleşme kuramı tartışmalarında, eski sömürgeler için bir "devlet yaratma” modeli olarak geliştirildiğine dikkat çekerken, yaratılmak istenen devletin, Batı tarzı devlet olduğunu belirtir (Kansu, 2009: 18).

Modernleşme kuramı Batı-merkezci yaklaşımı ve tarih dışılığı başta olmak üzere birçok konuda eleştirilmiş, yirminci yüzyılın ikinci yarısından sonra postmodernizm tartışmaları modernleşme tartışmalarına eşlik etmeye başlamıştır. Frankfurt ekolü, Marksist gelenek ve tarihsel yorumsamacı gelenek içinden gelen farklı yazarlar, modernleşme kuramına yerinde eleştiriler getirmişlerdir. Modernleşme kuramına getirilen eleştirileri iki ana başlık altında toplamak mümkündür. İlk eleştiri, modernleşme kuramının modern ve geleneksel olanı kesin bir ayrımla ele almasıdır. Ancak modern olan ile geleneksel olan keskin bir ayrıma sahip değildir; geleneksel toplumlarda modernleşme süreci sıklıkla diyalektik bir görünüme sahiptir. İkinci eleştiri ise tek tip tarih anlayışı çerçevesinde düşünülmesidir; oysa tarih tek bir çizgi üzerinden ilerlememekte ve her toplum kendi kültürel mirası ve tarihselliği içerisinde ilerlemektedir. Batı'da olan ya da Batı'ya uygun olan modelin birebir uygulanması, farklı ülkelerde farklı sonuçlar doğurabilmektedir. Batı'da var olanın meşru tek model olarak görülmeye başlanmasıyla birlikte Batı dışı toplumlarda ortaya çıkan hızlı rejim değişiklikleri toplumsal ve siyasal dönüşümlerin yüzeysel kalmasına ve süreç içerisinde toplumsal karmaşaların ortaya çıkmasına neden olabilmektedir. 


\section{Osmanlı-Türk Modernleşmesi: Kuramsal Yaklaşımlara Kısa Bakış}

Osmanlı'dan Cumhuriyet'e uzanan üç yüzyıllık modernleşme tarihi farklı adlandırmalarla karşımıza çıkar: Modernleşme, muasırlaşma, Batılılaşma ya da çağdaşlaşma. Yaşanan sürecin farklı biçimlerde isimlendirilmesi, genel bir kararsızlığın dışavurumundan çok Batı'daki dinamiğin aksine değişimin kümülatif biçimde gerçekleşmemesi ve birbiriyle uyumsuz toplumsal örüntülerin varlığından kaynaklanmaktadır. En yalın ifadesiyle, imparatorluğun kendini tarif etme dilini ve Batı'ya ilişkin algılamalarını farklılaştırırken erişilmesi gereken hedef olarak gözetilen modernleşme, bir siyasi proje olarak çok sayıda kusuruyla birlikte ortaya çıkmış ve gelişmiştir.

Osmanlı ve Türk modernleşmesi, yirminci yüzyıl Türkiye yazınında oldukça geniş bir literatüre sahiptir. İmparatorluğun son bulması ve Cumhuriyet'in ilanı ile yeni bir yönetim şekline geçiş yapılırken, erken Cumhuriyet döneminde resmi tarih yazımı, imparatorluktan kopuş yönünde geliştirilirken, yeni ulus-devletin tamamen farklı bir devlet olduğu vurgusu üzerinde durulmuştur. Erken Cumhuriyet döneminde modernleşme çalışmaları resmi tarih yazımıyla paralel bir görünüme sahip olmuş ve Kemalist ideolojiyi desteklemek üzere Türk modernleşmesinin özgünlüğüne yönelik çalışmalar literatürün çoğunluğunu oluşturmuştur. Epistemolojik olarak pozitivist bir çizgide ilerleyen bu çalışmalara, sosyal bilimlerde davranışçı geleneğin rağbet gördüğü ve modernleşme kuramının belirginleştiği 1960’lı yıllarda, modernleşme kuramı perspektifinden yazılan çalışmalar dahil olmuştur. Metin Heper, Ersin Kalaycıŏlu, Ergun Özbudan, İlter Turan, Niyazi Berkes gibi öncü isimler ve daha birçokları modernleşme kuramı ve davranışçı gelenek çerçevesinde eserler vermişlerdir. Modernleşme kuramı çerçevesinde verilen eserler çoğunlukla Cumhuriyetçi tarihsel yorum ve liberal demokratik çizgide yazılmakla birlikte, devletçi ve milliyetçi okumalar da yapılmıştır (Demirel, 2019: 54-58). Doğan, davranışçı gelenek içerisinde, modernleşme kuramının pozitivist çizgisinin uzun yıllar Türkiye yazınında hâkim olmasında, OsmanlıTürk tarihinin genellikle seçici bir biçimde ele alınarak geçmiş ile köklü bir kopuşu amaçlayan Cumhuriyetçi kültür politikalarının "tarihsiz" denebilecek bir kuşağın ortaya çıkışını kolaylaştırmış olmasının etkili olduğunu iddia eder (Doğan, 2002: 463). Kansu ise Türkiye'de modernleşme kuramına süreklilik ve kopukluk üzerinden farklı yorumlar geliştirildiğini söyler (Kansu, 2009: 18). Kopukluk tezini savunanlar, yüzyıllardır süregiden bir devlet yapısının 1923’te tamamıyla çöktüğü, bağımsızlığın kaybedilmesi sonrası yeni bir devletin kurulduğu üzerinden iddialarını geliştirir; süreklilik tezini savunanlar ise modernleşme kuramının doğal bir sonucu olarak Osmanlı'dan Cumhuriyet'e geçişte kurumsal, örgütsel ve kültürel devamlılıkların altını çizer. 
Türkiye sosyal bilimler yazınında 1961 sonrası görece özgürlükçü bir ortamın gelişmesiyle, modernleşme kuramının yanı sıra Marksist yaklaşım ve 1990 sonrası ise tarihsel yorumsamacı yaklaşım çerçevesinde eserler verilmiştir. Muzaffer Şerif, Korkut Boratav, Behice Boran, Sungur Savran, İdris Küçükömer gibi öncü isimlerin yanı sıra birçok isim, sosyalist veya Marksist olmanın milliyetçiliğe ve milli devlete karşı olmak olarak algılandığı yıllarda sosyalist veya Marksist çizgide eserler vermiştir (Demirel, 2019: 81). Bu yazarlar, Osmanlı ve Türkiye modernleşmesi kapsamında ATÜT, emperyalizm, sömürge, üretim ilişkileri gibi önemli konularda eserler vermişlerdir. Tarihsel yorumsamacı yaklaşımları ise pozitivizm ve Marksizm arasında üçüncü bir yol olarak görmek mümkündür. Cemil Oktay, Nilüfer Göle, Nur Vergin, Ali Yaşar Sarıbay, Şerif Mardin gibi öncü isimler her toplumun kendi kültürüne ve tarihine bakılması gerekliliği üzerinden tartışmalar geliştirmiştir. Bu yaklaşıma göre, bilim, kültürü ve tarihi değil; tarih ve kültür, bilimi öncelemelidir: tarih dışı, zaman ve mekândan bağımsız, kültür üstü bir bilgi ve bilimsel faaliyet düşünmek mümkün değildir; bilimsel faaliyetin kendisi zamana, mekâna ve kültüre bağımlıdır (Demirel, 2019: 136). Böylece, tarihsel yorumsamacı yaklaşımın modernleşme kuramının anti-tezi olarak geliştiği iddia edilebilir.

\section{6'ya kadar Osmanlı'da Modernleşme Hareketleri}

Osmanlı modernleşmesinin ne zaman başladığı konusunda literatürde oydaşma söz konusu değildir. Hâkim yazında III. Selim ile başlatılan Osmanlı modernleşmesinin tarihsel uğrakları; II. Mahmud dönemi, 1839 Tanzimat Fermanı, 1876 I. Meşrutiyet ve 1908 II. Meşrutiyet'tir. Modernleşmenin arka planını askeri yenilgiler nedeniyle cihan imparatorluğu söyleminin terk edilerek teknik üstünlüğün Batı'da olduğunun kabul edildiği fikri oluşturur. Eski, güçlü günlere dönmeyi hedefleyen önceki yüzyılların reform anlayış1nın yerini on dokuzuncu yüzyılla birlikte Batı'nın model olarak görüldüğü bir reform anlayışı alır. Modernleşmenin askeri alanın dışına çıkıp topyekûn bir reform hareketine dönüşmesi ise bilhassa II. Mahmud dönemiyle başlar.

On yedinci yüzyılla birlikte teknolojik ve bilimsel gelişmenin ışığında Avrupa'da hem orduların örgütlenme şeklinde hem de savaş yöntemlerinde değişiklikler meydana gelmiştir. Askeri alanda meydana gelen değişiklikler siyasal örgütlenme biçimlerinin ve ekonomik yapılarının değişimini beraberinde getirmiştir. Ortaya çıkan yeni savaş tekniklerinin yanı sıra savaş fikrinin rasyonel bir mahiyet kazanması onun doğasını değiştirmiş, orduların vuruş gücünü artırmıştır; askeri sistemde meydana gelen değişiklikler merkezi otoritenin güçlendirilmesini zorunlu hale getirirken bu durum modern devletlerin ortaya çıkmasına katkı sağlamıştır (Yeşil, 2016: 155). 
Osmanlı'nın Batı'da meydana gelen askeri ve teknolojik gelişmeleri takip edememesi klasik dönemde kendisini güçlü kılan askeri ve ekonomik üstünlüğünü kaybetmesine neden olmuştur. Osmanlı'nın askeri üstünlüğü on yedinci yüzyılla birlikte zayıflamaya başlarken on sekizinci yüzyılda bu üstünlük son bulmuştur. On sekizinci yüzyıl savaşlarının yenilgiyle sonuçlanması Avrupa'nın askeri üstünlüğünün kabul edilmesine neden olurken 1768-1774 yılları arasında gerçekleşen Osmanlı-Rus savaşında Osmanlı'nın Ruslar karşısında başarısız olması askeri modernleşmeyi kaçınılmaz hale getirmiştir. Böylece, on yedinci yüzyılda ortaya çıkan denklik kabulü (Lewis, 2008: 58) yerini on sekizinci yüzyılla birlikte Batı'nın askeri üstünlüğünün kabul edilmesi ve bu üstünlüğü sağlayan araçların imparatorluğa taşınması düşüncesine bırakmıştır (Mardin, 2018: 10). Berkes bu dönemde gerçekleşen reformların temelinde yatan iki fikre işaret eder (Berkes, 2019: 73): “On sekizinci yüzyıl sahnesinin açılmasıyla Osmanlı devletinin geleneksel kurumlarını diriltmeye dönme yerine çağdaş Batı'ya yönelme eğiliminde olduğunu, bu yolda başlıca iki yeni fikrini gördük. Bunlardan biri devlet gücünü desteklemek gerektiği, öteki bunun gerçekleşmesi için teknolojik ve ekonomik kalkınmanın zorunlu olduğu fikridir." Bununla birlikte, on dokuzuncu yüzyıla kadar gerçekleştirilen reformlar amaçlarına ulaşmamış olsa dahi on dokuzuncu yüzyılda gerçekleştirilen reformların temelini oluşturmuşlardır (Davison, 2005: 20). On dokuzuncu yüzyıl, daha köklü reformlarla “devleti kurtarma”nın amaçlandığı ve bu amaca Batılı yöntemlerle varılmaya çalışılan bir yüzyıldır.

Dikkat edilmesi gereken temel husus, on sekizinci yüzyll sonunda başlayan ve on dokuzuncu yüzyıla damgasını vuran Osmanlı'da modernleşmenin, askeri ihtiyaçlar doğrultusunda ortaya çıkmış olmasına karşın yönetim alanında dönüşümü beraberinde getirmiş olmasıdır. Savaşan askerlerin temin edilme şekli, uzmanlaşmanın ne şekilde gerçekleşeceği, savaşın maliyetinin hangi bütçeden karşılanacağı, değişen teknolojiye uygun askeri ekipmanların nasıl, nereden, kim tarafından temin edileceğine kadar birçok önemli husus nasıl ki Avrupa'nın yönetim sisteminde değişiklikler meydana getirdiyse Osmanlı için de bu durum geçerli olmuştur. Bu kapsamda Berkes, askeri modernleşmenin yayılan etkisini şöyle tarif eder (Berkes, 2019: 77): “Çünkü militer sorunu çözümlemek için teknolojik sorunu, onu çözümlemek için de ekonomi ve maliye sorununu ele almak gerekti."

Ortaylı, Osmanlı'nın modernleşmeye Batı modeline göre ve pragmatik bir yaklaşımla baktığına dikkat çekmektedir (Ortaylı, 2018). Bununla birlikte, Osmanlı'da modernleşmenin Batı'ya duyulan hayranlığın değil bir zorunluluğun sonucu olduğunu belirtir. Ayrıca, Osmanlı bu reformları gerçekleştirirken dış 
baskıların etkisini hissetmiş olsa da sadece baskılar sonucunda değil Osmanlı'nın kendi inisiyatifiyle gerçekleştiğini vurgular. Ortaylı'nın ve diğer birçok yazarın hem fikir olduğu konu ise Osmanlı modernleşmesinin "otokratik bir modernleşme” olduğudur (2018: 34). Bu görüş ekseninde, padişahlar veya paşalar tarafından gerçekleştirilen reformların yukarıdan modernleşme mantığıyla uygulandığı ve bu nedenle Batılı olmayan devletlerin modernleşme hareketlerine zıt bir şekilde daha hızlı ve tarihsellikten kopuk bir şekilde gerçekleştiği savunulur. Parla ise Osmanlı modernleşme sürecinin "savunmacı modernleşme" olarak adlandırıldığına dikkat çekerken, modernleşmenin her zaman için bir Batılılaşma anlamı taşıdığını ve Osmanlı’nın güçlüye direnme yöntemi olarak kendini onla özdeştirmeyi tercih ettiği ifade eder (Parla, 2009: 23). Böylece modernleşmenin otokratik yapısı toplumsal alanda toplum tarafından gerçekleştirilmesi gereken reformların dahi devlet eliyle gerçekleşmesine neden olmuştur.

Yine Ortaylı on dokuzuncu yüzyılı düalizm asrı olarak tanımlarken, bu yüzyılda geleneksel olan ile modern olanın birlikte var olduğuna dikkat çekmektedir. Osmanlı modernleşmesinin düalist yapısı modernleşmenin temel çatışmasının modern ile geleneksel arasında yaşanmasına neden olmuştur. Köker yüzyıl boyunca Batı'daki modern kurumların Osmanlı'da oluşturulması amacıyla idare, eğitim, hukuk gibi birçok alanda yapılan reformların temel çatışma alanının din olduğuna dikkat çekerek “devleti güçlendirmek amacıyla alınan Batı kurumları, devletin temelini oluşturan en önemli öge olarak din ile çatışmakta mıdır (Köker, 2016: 132)?" sorusunu sorar ve bu soruya olumlu bir cevap verip reformların din ile çatıştığını iddia eder. Buna ek olarak Köker, bu yüzyılda Batı tipi örnek alınarak oluşturulan kurumların geleneksel yöntemlerle bütünleştirilmesini savunanlar ile bunlara karşı gelerek sadece geleneksel yapının ihyasını savunanlar arasında bir fikir çatışması olduğuna dikkat çeker. Aslında bu yüzyıl boyunca karar alma mekanizmalarında yer alan paşaların hemen hemen hepsinin Batı'da eğitim aldığı ve paşaların Batı tarzı modernleşmeyi zaruri gördüğü bilinen bir gerçektir. Ancak modernleşme sürecinde dinin ve hâkim kültürün ne şekilde ele alınacağı konusunda farklı düşünen Batı taraftarı ve Batı karşıtı gruplar dönemin temel fikri çatışmasını oluşturur. Batı karşıtı gruplar, yapılacak olan Batı tarzı reformların, kurumların yenilenmesi ve teknik geriliğin önüne geçilmesiyle sınırlı kalması gerektiğini savunmakta, toplumsal, dini ve ahlaki yapının korunması gerekliliğine inanmaktadır. Örneğin askeri alanda yapılacak reformlar gereklilik olarak görülürken, örfi hukuk kurallarının değiştirilmesine ve seküler hukuk reformlarının yapılmasına toplumsal ve dini yapıya zarar vereceği düşüncesiyle karşı çıkmaktadırlar. Batı tarafları gruplar ise sadece 
kurumsal veya teknik reformlar çerçevesiyle sınırlanmış reformların istenen ilerleme için yeterli olmayacağını savunmaktadırlar. Aynı örnekten devam edecek olursak Batı taraftarı gruplar, örfi hukuk kurallarının geleneksel çizgisinin değiştirilmesi gerekliliğine inanmakta ve Batı tarzı düzenlemelerin zorunluluğuna dikkat çekmektedir. Bu minvalde, taraflar arası yorum farklılıkları geleneksel-modern ikiliği tartışmasının dini konuları içerecek şekilde ilerlemesini beraberinde getirmiştir. Tarafların reformlar konusunda farklı yorum ve taleplerine rağmen hem fikir oldukları konu ise Batı'nın teknik üstünlüğüdür. Her iki taraf da üstünlüğü kabul ederken, hangi tarafın daha ilerleme yanlısı olduğu yüzyıla hâkim olmuş bir tartışmadır.

Fikri ayrılıkların yanı sıra askeri alandan ekonomik, siyasal ve toplumsal alanlara yayılan modernleşmenin hangi uygulamalar ışığında değiştiğine bakmak gerekmektedir. III. Ahmet, I. Mahmud, I. Abdülhamid dönemlerinde daha belirgin şekilde ortaya çıkan Batı'nın askeri kurumlarını örnek alma girişimleri, on dokuzuncu yüzyıl reformları açısından bir ders niteliğinde olan III. Selim reformlarıyla en yüksek seviyeye ulaşmıştır. III. Selim'in gerçekleştirmiş olduğu Nizam-1 Cedid reformları 1807 yılında son bulmuştur. Dini ve askeri kanadı temsil eden Şeyhülislam ve Yeniçeri ağasının başını çektiği reform karşıtları, 1807 yılında reformcu padişah Selim'in tahtan indirilmesine ve reformların son bulmasına neden olmuştur (Lewis, 2008: 104). III. Selim'in tahtan indirilmesinde gerekçe olarak gösterilen Selim'in yapt1ğı reformların dinden ve kültürden kopuşa neden olduğu iddiası, Selim'den itibaren Osmanlı modernleşmesine muhalif olan muhafazakâr kanadın temel iddiası olagelecektir. Nizam-1 Cedid, askeri alanda yenilikçi ve modern orduların oluşturulması fikriyle ortaya çıkarken, Yeniçeri Ocağı geleneksel yapının korunması taraftarı olarak modern askerlik eğitimine ve bu amaçla gerçekleştirilecek reformlara karşı çıkmıştır. Bununla birlikte, Berkes'in de belirttiği üzere, reformlar askeri alanla sınırlı kalmayarak bir rejim veya sistem olarak "Nizam-ı Cedid anlayışı” haline gelmiştir (Berkes, 2019: 101): "İlk defa olarak devlet himayesinde ve çevresinde daha önce bulunmayan bir tip, eskinin ulema ocağının yerine 'bir aydın tipi', daha sonra değişecek olan modern intelligentsia'nın öncüleri olarak doğmak üzeredir... Bundan başka bilgisizlik ve taassup karşıtı olarak bilim ve aydınlanma ayrımı yapılmaktadır." Ortaya çıkan yeni aydın sınıf, III. Selim'in diplomasi yönünde yaptığı reformların bir yansımasıdır. Avrupa'nın önemli başkentlerinde düzenli ve kalıcı elçilikler açmaya başlamasıyla birlikte bu elçiliklerde görev alan ve dolayısıyla Batı ile yakın temas halinde olan bir grubu ortaya çıkarmıştır: Din eğitimi almamış sivil ve hür Türkler yeni açılan elçiliklerde çalışmaya başlamış; elçiliklerdeki görevleri bitip ülkeye döndüklerinde Başkent'in etkin 
isimleri haline gelirlerken Batı tipi reform yanlısı gruplara da öncülük etmişlerdir (Lewis, 2008: 86). Bu minvalde, Yeniçeri Ocağı Nizam-1 Cedid'in askeri uygulamalarına karşı çıkan grup olarak belirirken, ulema da bu yeni tip aydın sınıfının reformlarını eleştirmiştir. Nihai olarak III. Selim'in tahttan indirilmesinde her iki grup da etkili olmuştur. Osmanlı modernleşmesine direnen iki ana kurumdan biri olan Yeniçerilik, II. Mahmud döneminde lağvedilip ortadan kaldırılırken, ulema sınıfı modernleşmenin dinden kopuş olduğu gerekçesiyle modernleşme ve dini çatışan iki olgu olarak ele almaya ve modernleşme hareketlerine karşı olmaya devam etmiştir.

On dokuzuncu yüzyıl Sened-i İttifak'ın imzalandığı, Yeniçeri Ocağı'nın lağvedildiği, Tanzimat ve Islahat Fermanlarıyla padişahın yetkileri sınırlanırken bürokrasinin ve merkezi otoritenin güçlendirilmeye çalışıldığı, Birinci Meşrutiyet ve Kanun-i Esasi'nin ilanıyla anayasal yönetim anlayışına geçişin sağlandığı, Osmanlı’nın geleneksel yönetim anlayışında köklü değişikliklerin meydana geldiği ve modern devletin temellerinin atıldığı bir yüzyıldır. Ahmad bu görüşe karşın yönetim şekli açısından klasik dönemden keskin bir kopuşun bu yüzyılda yaşanmamış olduğunu iddia eder; patrimonyal yönetim anlayışı devam etmektedir, iktidar hala müdahaleci ve merkezidir ancak bu süreklilikle birlikte özellikle 1839 sonrası yapılan reformlarla Tanzimat devletinin klasik devletten farklılaştığı görülmektedir (Ahmad, 2008: 39): “Tanzimat'in hedefi, tamamen yeni bir sosyal devlet yaratmaktı. Devlet müdahalesi artık sadece toplumu düzenlemek için düşünülüyordu; bu müdahalenin ama$\mathrm{cl}$ artık toplumsal mühendislikti." Bu noktada, Tanzimat reformlarına geçmeden, Tanzimat uygulamaları için bir geçiş dönemi olarak düşünülebilecek, mutlakiyetçi aydın monarşi yaratma eğilimi olarak tanımlanabilecek II. Mahmud dönemi reformlarının mahiyetine kısaca bakmakta fayda bulunmaktadır. Berkes, II. Mahmud döneminde mutlakiyetçi monarşi şekline yöneliş olarak tanımladığı reformlar için dört özellik belirler (Berkes, 2019: 171): “Hükümdarın mutlak yetki hakkı devam eder; yönetilenler reaya olmaktan çıkıp, tebaa ve halk oluyor; kapı kulluğu kalkıyor onun yerine sınıf, ırk, din farkları gözetmeden bir sivil bürokrasi gelişiyor; kapıkulu ordusu yerine farklı şekilde devşirilecek bir militer örgüt kurulmasına doğru gidiliyor; sivil bürokrasi ve ordunun başında bulunanlarla ulemadan seçilen kişilerden oluşan en üst yetkili, kanun yapma görevlisi sürekli meclisler kuruluyor." II. Mahmud'un yaratmaya çalıştığı rejimin -aşağıda izi sürüleceği üzere- Tanzimat dönemine yansımaları mevcuttur. Örneğin, Tanzimat dönemine damgasını vuran sivil bürokrasi II. Mahmud döneminde oluşmaya başlamıştır. Başka bir örnek, Ahmad'ın toplum mühendisliği olarak bahsettiği sivil bürokrasi tarafından yapılan reformların, II. Mahmud döneminde halka rağmen, halkın iyiliği için, 
halk karşısına çıkmış bir aydın monark tarafından gerçekleştirilmiş olması verilebilir (Berkes, 2019: 172). Ayrıca II. Mahmud'un Yeniçeri Ocağı'nı lağvetmesi, kendi kontrolü altında tutmayı başardığı sivil bürokrasiyi daha etkin çalışır hale getirmiş ve böylece Tanzimat bürokratlarına zemin hazırlamıştır (Davison, 2005: 31-32). Tanzimat'a aktarılan bir diğer özellik ise II. Mahmud döneminde öncülüğü yapılan seküler devlet yaklaşımı ve yine bu dönemde yetiştirilen seküler sivil bürokrasidir (Heper, 2018: 86).

II. Mahmud döneminde padişah eliyle gerçekleştirilen reformlar, Tanzimat döneminde sivil bürokratlar öncülüğünde gerçekleşmiş, bu durum II. Abdülhamid dönemine kadar devam etmiştir. Tanzimat Fermanı siyasal açıdan kritik bir uğraktır. Zira bu dönem, önceki dönemlerden beri amaçlanan modern merkeziyetçiliğin kurulduğu dönemdir (Ortaylı, 2018: 93). Modern devlet olmanın gerekliliğini içeren maddeleriyle Tanzimat Fermanı, devleti siyasi, sosyal ve ekonomik açılardan yeniden düzenlemeyi hedefler. Başta merkez yönetimi olmak üzere taşra teşkilatı, güvenlik, ordu, eğitim-öğretim, basın yayın, sağlık, dış ilişkiler, maliye ve ekonomi alanlarında reformlar yapılır (Çadırcı, 1999: 183). Uzmanlaşmış sivil bürokratların yer aldığı bir taşra teşkilatlanmasının temellerinin atılması açısından da Tanzimat önemli bir dönemdir. Ancak çok geniş topraklara sahip Osmanlı'nın, bu reformları devletin her yerinde aynı ölçüde uyguladığı söylenemez. Bunun mümkün olmamasına yol açan en büyük neden, reformları uygulayacak olan personeli yetiştirmeye yönelik sistematik bir politika güdülmemesi ve dolayısıyla imparatorluğun bütün topraklarında görevlendirilecek yetişmiş elemanların olmamasıdır (Akyıldız, 2012: 79-80).

Tanzimat dönemi devlet adamları otoriter bir yönetimin temsilcisi olarak merkeziyetçiliği güçlendirirken, bu dönemde çıkarılan kanunlar ve tesis edilen kurumlar Cumhuriyet dönemi modernleşmesinin temelini atmış ve Osmanlı toplumunda siyasal modernleşmenin hızlanmasını sağlamıştır (Ortaylı, 2018: 95). Merkezileştirme, bir taraftan sosyal yapıyla uyumsuzluk yaratırken bir taraftan kurumsallaşmayı sağlar. Nitekim Deringil bu dönemde yapılan bazı reformlarla bugünkü anlamda modern devlete geçişin başladığına dikkat çeker (Deringil, 2014: 22): “Örgün eğitimin benimsenmesi, posta hizmetleri, demiryolları, fenerler, saat kuleleri, cankurtaran sandalları, müzeler, nüfus sayımları, doğum sertifikalan ve pasaportların yanı sıra, parlamentolara, bürokrasiler ile ordulara sahip bir devlet.”

Berkes ise kanunlaştırma sürecini Osmanlı geleneği içinde modernleşme sürecinin bir parçası olarak ele alır (Berkes, 2019: 221). Bu bakımdan Tanzimat'ın kanunlaştırma süreci sayesinde bürokratlar gücünü 
kanunlardan alırken, aynı kanunlara dayanarak merkezi otoritenin güçlendirilmesi bürokrasinin güçlendirilmesini beraberinde getirmiştir. Metin Heper, 1830'dan itibaren etkili olduğunu iddia ettiği bürokratik sınıfın II. Mahmud tarafından öncülüğü yapılan seküler devletin temsilcisi olduğuna dikkat çeker: (Heper, 2018: 33) “Geleneksel adab geleneği en seküler biçimde diriltiliyor; devlet siyasetinin tek ölçütünün 'akıl' olması gerektiği ileri sürülüyordu." Heper ayrıca Tanzimat dönemini geleneksel devlet anlayışı içerisinde ılımlı aşkıncı bir devletin ortaya çıktığını, Cumhuriyet dönemine miras kalacak bu devlet anlayışının uygulanmasındaki sıkıntıları ise şöyle tarif eder (Heper, 2018: 88): "Performansa dayalı liyakat gibi rasyonel ölçütler benimsenmedi; hiyerarşi gibi salt bürokratik ölçütler ön plana çıkarıldı... Bürokrasinin rasyonel boyutundan ziyade hukuksal boyutuna önem verildi..." Keyder ise sivil bürokrasinin laik kimliğine dikkat çekerken, hem siyasal alanda hem de ekonomik alanda yapılması hedeflenen reformların yapılabilirlik kıstası olarak Avrupa'yı ele alan bu sınıfın, Avrupa kapitalizmini benimsediğini; Avrupa'da meydana gelen modellere ve ilkelere bağımlı kaldıklarını ve daha önemlisi kendi sınıfsal ayrıcalıklarını korumaya yönelik reformlar yaptıklarını belirtir (Keyder, 2014: 41). Aslında Keyder'in dikkat çekmek istediği konu, dönemin modernleşme hareketinin diğer sınıfların çıkarlarından veya taleplerinden bağımsız bir şekilde tek bir sınıfın çıkar ve hedefleri doğrultusunda ortaya çıkmasıdır. Ayrıca toplum açısından önemli bir konu olan toplumsal sinıfların örgütlenme şekli bu dönemde, cemaat tipi toplumsal örgütlenme şeklini koruyarak devam etse de gerilemeye başlamıştır (Ortaylı, 2018: 100): "Bireyler bir zaman sonra dini özgürleşmeden çok, ekonomik ve siyasal özdeşleşme ile bir araya gelmeye başlayacaktır. Yarım yüzyıl sonra ayrı dinden insanlar bir siyasi cemiyetin etrafında Meşrutiyet devrimine katılacaklardı.” Buradan hareketle Tanzimat döneminin cemaat tipi örgütlenmenin gerilemesi, laik düşünce ortamına zemin hazırlamıştır. Ancak bu laikleşme halka kadar inmemiş; bu dönemde bürokratların eğitimi için açılan okullar aracılığıyla laikleşme/çağdaşlaşma süreci kurumsallaşmış; daha sonra medreselerin kaldırılışında ve ulemanın etkinliğinin azalmasında bu dönemin laikleşme reformları etkili olmuştur (Parla, 2009: 26).

Tedrici olarak gerçekleşen Osmanlı modernleşmesinde, hangi alanda yenilik yapılacağı seçmeci bir mantıkla gelişmiştir. Peki, toplumun bir kesiminin tepkisine neden olan reformlar ne derece hayata geçirilebilmiştir? Davison; III. Selim ve II. Mahmud'un çabaları üstünde yükselen Tanzimat reformlarının yarım kalmış tedbirler, kısmi başarılar ve tam başarısızlıklar veya sadece kâğıt üzerinde kalmış reformlar olmak üzere birçoğunun ortak kaderi paylaştıklarını dile getirir (Davison, 2005: 50). Diğer taraftan Tanzimat 
kurumlarında laikleşme girişimleri belirgin bir düalist yapı ve bundan kaynaklanan sorunlar yaratır. Örneğin din farkı gözetmeksizin yürürlüğe giren Ceza Kanunnamesi hukuk sisteminin ikili yapısına çarpar. Buna göre savcı resmen kamu adına dava açma yetkisine sahipken, isteyenler dava için kadıya müracaat edebilmektedir (Ortaylı, 1995: 180). İkili duruma benzeri bir diğer örnek Ahmet Cevdet Paşa başkanlığında 1868-1876 yıllarında hazırlanan Mecelle'dir. Var olan ihtiyaç doğrultusunda ve bir medeni kanun mantığıyla hazırlanan Mecelle'de aile ve miras hukukuna yönelik hükümlere yer verilmemekte, sadece borçlar, eşya ve usul hukukuna yönelik hükümler yer almakta ve bu alanlarda tebaanın aynı hükümlere tabii olması amaçlanmaktadır (Osmanağaoğlu Karahasanoğlu, 2011: 105). Aile ve miras hukukuna yer verilmemesinin nedeni, tebaanın dini farklılıklarının göz önünde bulundurulması ile Müslüman ve Müslüman olmayan nüfus ayrımının gözetilmesidir. Bununla birlikte Mecelle, Hanefi mezhebi içtihadları çerçevesinde hazırlanmış modern bir kanunlaştırma girişimidir: Farklı uygulamaların önüne geçmek amacıyla hakimlerin kararlarının farklı mezheplere veya ekollere göre verilmesi yasaklanmıştır (Aydın, 2003: 233). Osmanağaoğlu Karahasanoğlu'nun da dikkat çektiği üzere tüm hukuk normlarının, aile ve miras hukuku da dahil, din farkı gözetmeksizin devletin tüm tebaası için aynı olması modern devlete ait bir özelliktir. Bu minvalde Mecelle, tebaa arasında hukuk birliğinin sağlanmasından ziyade modern hukuk sistemine geçişte bir aşama olarak görülebilir (Osmanağaoğlu Karahasanoğlu, 2011: 106).

Berkes de Tanzimat'ın yaşadığı en büyük sorunun kanunlaştırma konusunda olduğunu belirtir: "Tanzimat rejiminin çözmeye çalıştığı en büyük sorun; yasama gücü ile yürütme gücü, yasama gücü ile adalet gücü, adalet gücü ile yürütme gücü arası ilişkiler olmuştur. (...) Hanefi olan Osmanlı geleneğinde, birçok İslam devletlerinden farklı olarak kadı yalnız şeriat hukukunu değil, kanun hukukunu da uygulayan bir yargıç olmakla birlikte, kadının yargisına geniş bir alan bırakılıyordu. Şeriat ve kanunu birleştiren bir sistemin düzenli gidişinde iyi işleyen böyle bir adalet sistemi, o sistemde hem siyasal hem dinsel bozuluş başlayınca zulüm, adaletsizlik, rüşvet, yetkiyi kötüye kullanma gibi korkunç sonuçlara yol açar" (Berkes, 2019: 220-221).

Tanzimat yöneticileri yaptıkları reformlarla özelikle Batı ile ekonomik anlamda bütünleşmenin yollarını ararken, aslında çıkarılan fermanlarla toplumsal kırılma noktaları oluşturduklarının bilincinde değildir. 1856 Fermanı, askerlik hizmetinde, adalet idaresi alanında, vergilerde, sivil ve askeri okullara alınmada, kamu işlerine girmede ve toplum içinde saygı görmede herkesi eşit olarak tanımlıyor (Davison, 2005: 57); böylece Osmanlı millet sistemine son verilirken tebaa din, dil, ırk ayrımı yapmaksızın eşit olarak görülüyordu. Bu 
eşitlik gayesi, teoride ileri bir modernleşme hareketi olarak görünse de uygulamada birtakım sıkıntıları beraberinde getiren fermanlar, farklı kesimler tarafından eleştirilere maruz kalmıştır. Hiç kuşkusuz yönetimin amacı, Osmanlıcılık fikrini oluşturmak ve yayılan milliyetçi hareketlere karşı devleti bir arada tutmak olmuştur; ancak bu çaba sonuçsuz kalmış reformlar kendi muhalefetini kendi yaratmıştır. Klasik dönem millet sisteminin yerine Osmanlı'daki milletleri eşitlemeyi hedefleyen Tanzimat reformları amaçlananın aksine asırlardır var olan dengenin bozulmasına neden olmuş, farklı etnik grupların çok olduğu Lübnan-Şam gibi bölgelerde kanlı çatışmalara dönen krizleri beraberinde getirmiş; umulanın aksine bu çatışmalar Batılı devletlerin müdahalesini de artırmıştır (Baktıaya, 2017).

Tanzimat reformlarının Batı'nın desteğini alan diğer etnik grupları Türklere karşı avantajlı konuma getirdiği iddiası Tanzimat uygulamalarına muhalif olan Yeni Osmanlılar tarafından sıklıkla dile getirilmiştir. Bu noktada Yeni Osmanlılara kısaca değinmekte faydalı olacaktır. Yeni Osmanlıların Osmanlı İmparatorluğu'nun ilk siyasal muhalif hareket olduğunu iddia etmek mümkündür. Hareketin öncü isimleri olan Namık Kemal, Nuri Bey, Reşat Bey, Ayetullah Bey, Refik Bey gibi isimlerin yanı sıra Mustafa Fazıl, Ali Suavi, Ziya Paşa gibi isimler de hareket içerisindeki önemli isimlerdir. Osmanlı modernleşmesinin görüngülerinden biri olan Tercüme Odası geleneğinde yetişen, çoğunluğu çeşitli devlet kademelerinde memurluk yapmış isimlerden oluşan Yeni Osmanlıları Koçak, söyle tarif etmektedir (Koçak, 2009: 77): “Batı'ya açılan bir pencerede, yabancı bir dil, yeni ve modern olan ile yakın temas ve etkileşim, yönetici elitin hiyerarşik basamakları göreli olarak daha süratli bir ilerleme imkânı, hepsi bu temele dayanıyordu." Koçak'ın Batı'ya açılan penceresi Tercüme Odası'dır. Ayrıca Yeni Osmanlılar içerisindeki birçok isim Avrupa'da eğitim görmüş, Avrupa'daki gelişmeleri yakından takip etmişlerdir. Fikir, talep ve hedeflerini çeşitli gazete ve dergiler aracılığıyla duyurmuşlardır. Yeni Osmanlıların temel hedefleri “devleti kurtarmak”tır. $\mathrm{Bu}$ hedef çerçevesinde dinsel gelenekçilik ile siyasal liberalizmi bir araya getirmeye çalışmışlar ve böylece İslami idealleri ve kavramları kullanmayı terk etmeden Batı tarzı modernleşmeyi savunmuşlardır (Hanioğlu, tarih yok: 27). I. Meşrutiyet'in ilanındaki etkileri göz önünde bulundurulduğunda taleplerinin kısa süreliğine de olsa gerçekleştiği de iddia edilebilir. Mardin Tanzimat yönetimine muhalif Yeni Osmanlıların temel hedefini şu şekilde tarif eder (Mardin, 2017b: 58): “Bir milli temsil organın kurulması, Türkiye’nin iç işlerine yabancı müdahalesinin bertaraf edilmesi, reform meselesinin Osmanlı ve İslami bir çizgide çözümlenmesi gibi hedefler...” Belirtilen bu hedefler Tanzimat dönemi eleştirisini içerisinde barındırmakta ve Tanzimat 
paşalarının kendi otoritelerini artırmalarına karşı çıkarak, anayasal temsil sistemiyle paşaların bu güç devşirmelerine son vermeyi amaçlamaktadır. Onların gözünde Tanzimat paşaları Ali ve Fuad, Avrupa devletleri yönlendirmesi sonucunda fermanları ilan etmiş, Avrupa'nın Osmanlı'nın iç işlerine karışmasına olanak sağlamış ve Hristiyanlara ayrıcalık tanınarak devletin zayıflamasına neden olmuştur (Davison, 2005: 231). Bu bakımdan, dönemin modernleşmesine karşıt modernleşme taraftarı muhalif bir hareket olarak Yeni Osmanlıların bizatihi kendisi modernleşmeye içkin çelişkilerin ürünüdür.

Tanzimat dönemi modernleşmesine yapılan eleştirilerin diğer bir kaynağını, toplumsallıktan uzak olmaları ve Batı'dan ithal ettikleri kurumları toplumsal gerçekliklerle birleştiremedikleri fikirleri oluşturur. Bu eleştirilere göre, Tanzimat aynı zamanda devlet ve toplum diyalogsuzluğunun belirginleştiği, diyalog yerine emirlerle şekillenen bir monolog biçiminde devletin toplum karşısında yükseldiği bir dönemdir (Belge, 2012: 13). Davison, dönemin modernleşmesine yönetilen eleştirileri şöyle tarif eder (Davison, 2005: 421-422): “Tanzimat devlet adamlarının yabancı kurumları ithal etmeye ve onları Türk toplumuna aşılamaya girişmiş oldukları söylenir... Ancak çağın gereklerini karşılamak için Müslüman hukukunu, vakıf kurumunu ve medreseyi geliştirmeleri gerekirdi. Avrupai ve Osmanlı kurumlarını yan yana yaşatarak ölümcül bir ikilik yarattılar. Genelde sadece biçim konularıyla ilgilendiler, özle değil... Temsili yönetim kurumlarını, onları kabul etmeye hazır olmayan bir topluma dayattılar. Padişahın mutlakiyetçiliğini kendi mutlakiyetçiliğini dayatmak için reddettiler.” Bununla birlikte, Davison bazı eleştirmenlerin Tanzimatçıları daha radikal reformlar gerçekleştirmemekle eleştirdiklerini belirterek, Tanzimatçıların farklı kesimlerden eleştiriler geldiğine de dikkat çeker. Parla, Hurewitz'in bu dönem reformlarını "kapalı devre içinde modernleşme” olarak adlandırdığını aktarırken, askeri yönetsel, kurumsal ve yönetsel reformların yapıldığını ancak sosyal ve ekonomik alanlarda modernleşme olmadığını belirtir (Parla, 2009: 27). Ayrıca Parla, bu dönemde ekonominin yeteri kadar gelişmemesinin Avrupa sermayesine bağımlı bir ekonominin ortaya çıkmasına neden olduğunu ve bu bağımlılığın da devletin mali çöküşüyle sonuçlandığını iddia eder. Pamuk, reform süreci ve ekonominin dişa açılışını çelişkileriyle birlikte değerlendirir. Zira taşradaki unsurlar karşısında merkezi devletin gücünü artırma, orduyu ve maliyeyi güçlendirme girişimleri Osmanlı idarecilerini Avrupalı devletlerin desteğini almak zorunda bırakır. Avrupalı devletlerin, reformlara verdikleri destek karşılığında Osmanlı ekonomisinin dış ticarete ve yabancı sermayeye açılması yönündeki talepleri, reformların merkezi devletin ekonomi üzerindeki denetiminin azalmasına yol açar (Pamuk, 2007: 204). Batı'nın ekonomik egemenliğinin 
artmasının ve Batı ile girilen ticari ilişkilerin diğer sonucu Osmanlı'da toplumunda meydana getirdiği değişimdir. Batı ile özel bağları sayesinde ticaret yapmaya başlayan azınlıklar, iktidarın kontrolü dışında servet biriktirerek Osmanlı ticaret burjuvazisinin nüvesini oluştururlar (Göçek, 1999: 191-192).

I. Meşrutiyet'in ilanı ve Kanun-i Esasi'nin kabulü ile anayasal bir meşruiyet anlayışına geçilmesi, liberal demokrasiye ve temsil sistemine geçiş yapıldığı anlamına gelmemiş, dönemin bir gerekliliği olarak ortaya çıkmıştır. Batılı olmayan devletlerin modernleşme sürecinde yaşadıkları ikili yapı Osmanlıda da etkisini gösterirken, anayasal monarşiyi talep edenler padişahlık sistemine son verilmesi ya da saltanatın kaldırılması gibi "radikal" düşüncelere sahip değillerdi. Tanzimat döneminde padişahın yetkilerini kısıtlayan uygulamalara gidilse de padişahlık makamı saygı duyulan bir makam olmaya devam etmiştir. Özetle dönem boyunca modernleşme amacıyla eğitim, hukuk, idari sistem gibi farklı alanlarda birtakım reformlar yapılmış ancak geleneksel olandan vazgeçilmeyerek modern ve geleneksel bir arada yaşatılmaya çalışılmıştır.

\section{Meşrutiyet Sonrası Osmanlı Modernleşmesi}

Savunmacı karakterli ve eklektik olan Osmanlı modernleşmesi, zaman zaman yoğunlaşan zaman zaman duraksayan bir hale bürünmüş ve lineer bir çizgide ilerlememiştir. Mardin'in ifadesiyle, Batıcılık bazen ılımlı bazen köktenci boyutlarıyla karşımıza çıkmaktadır (Mardin, 2018: 11). Dolayısıyla başı sonu belli, monolitik bir modernleşme hareketinden söz etmek güç görünmektedir. Nilgün Toker ve Serdar Tekin, on sekizinci yüzyılın ilk yarısında başlayan, ama esasen on dokuzuncu yüzyılda gelişen Batılılaşma hareketlerinin, Cumhuriyet'in kuruluşuna kadar uzanan 150 ylllık süre içinde belirginleşen iki genel özellik taşıdığını söyler. İlk özellik, 'devletin korunup kollanması ve ihya edilmesi' türünden pratik bir amacın başlangıcından itibaren Batılılaşma hareketlerine yön veren temel saik olmasıdır. Bu durum Batıcı siyasi düşüncenin 'uygulamaya dönük' bir zihniyet içinde gelişmesine yol açmıştır. Kısmi reform anlayışı Batı'nın arkasında yatan bütünlüklü değer ve düşünce sisteminin geç anlaşılmasına yol aşmıştır. Eski değerler ve yeni kurumlar arasında çıkan çatışmanın kaynağı bu anlaşılmazlıkla ilişkilidir. İkinci özellik ise başlangıçta kısmi amaçlarla ortaya çıkan Batılılaşma hareketlerinin giderek 'topyekûn Batılılaşma' hamlesine dönüşmesidir. Bu süreç de 'Batılılaşma'dan bir program olarak 'Batıcılık’a geçiş olarak adlandırılabilir (Toker \& Tekin, 2007: 82). Toker ve Tekin'in ortaya koyduğu üzere Batı'ya ilişkin algılamanın değişmesiyle biçimlenen iki özellik modernleşmenin değişen karakterini betimlemek açısında faydalı araç sunabilir. 
Bu açıdan Tanzimat, Batı'ya bakışın daha olumlu olduğu bir dönemken, I. Meşrutiyet sonrası bu bakış yörünge değiştirir. II. Abdülhamid dönemi, hem Osmanlı'nın kendisine hem Batı'ya içkin algılamalarının yeni bir boyut kazandığı ve bu algılama değişikliği nedeniyle Osmanlı modernleşmesinin niteliğinin farklılaştığı uğraklardan biridir.

Berkes, 1871-1876 yıllarını İslamcılık akımının keskin bir biçim aldığı, Batılılaşma amacıyla elli yıldır gerçekleştirilen köklü reformların durduğu, din ve devlet ayrımı yönündeki gidişatın din-devlet bileşimiyle sonuçlandığı bir dönem olduğuna dikkat çeker (Berkes, 2019: 309). Davison ise Tanzimat Paşa'sı Ali'nin 1871'de ölmesiyle başlayan kaos döneminde, tedrici laikleşme, Osmanlılığın esas alınması ve dolayısıyla genel modernleşme politikasının sekteye uğradığını söyler (Davison, 2005: 280). Ali Paşa sonrası girilen bu kaos dönemi Osmanlı modernleşmesinin kişilere bağlı yapısını ve bu nedenle modernleşme hareketlerinin devamlı değil kopuk bir şekilde gerçekleştiğini göstermesi açısından iyi bir örnektir. Bununla birlikte, bu dönemde içeride ve dışarıda yaşanan ekonomik ve siyasal sıkıntılar reformlar açısından durgunluğu beraberinde getirmiştir. 1876 yılında yaşanan padişah krizleri II. Abdülhamid'in iktidarıyla son bulurken, halkların eşitliğinin sağlanması ve milliyetçi hareketlerin önüne geçilmesi gibi pratik ve acil amaçlar, Mithat Paşa ve diğerleri için Meşrutiyet'in ve anayasanın itici gücünü oluşturmuştur (2005: 377).

Abdülhamid'in kendi deyişiyle modernleşme memleketin hakiki şartları göz önünde tutularak yapılmalıdır (Georgeon, 2006: 278). Tanıl Bora, Ahmet Cevdet Paşa ve Ahmet Mithat'ın muhafazakâr modernleşme aklının Abdülhamid politikalarıyla uygulandığını belirterek bahsi geçen muhafazakarlığın dini tutuculuktan uzak devlet aklına sahip çıkan mutaassıp bir muhafazakarlık olduğunu ifade eder (Bora, 2018: 32). Abdülhamid döneminin ideolojik tartışmaları ve istibdat yönetiminin incelenmesi bu çalışmanın dışındadır. Ancak Abdülhamid'in genel olarak Pan-İslamcı olarak tanımlanmasına karşı çıkan Ahmad, Abdülhamid'in İslam'ı saldırı değil savunma aracı olarak kullandığını; Batı'ya karşı kendi konumunu güçlendirmek için halifelik konumunu ve siyasal İslam'ı kullandığı belirtir (Ahmad, 2006: 119). Önemli olan nokta, Abdülhamid'in dini siyasal araç olarak ele aldığının altının çizilmesi ve dini kaygiların modernleşme çabalarına engel teşkil etmesi gibi bir durumun söz konusu olmamasıdır.

Hem Abdülhamid'in hem de Abdülhamid muhaliflerinin ortak amacı tıpkı Tanzimatçılarınki gibi devletin kurtarılmasıdır. Uygulanan yöntem ve benimsenen ideoloji farklı olsa da Şerif Mardin'in de dikkat çektiği üzere aslında on dokuzuncu ve yirminci yüzyıldaki fikir akımları sistematik ya da 
tutarlı bir şekilde savunulmaktan öte kısa vadeli, pratik, devlet için çözüm yolları üreten, yalınkat bir pragmatizm içermekle beraber, devleti kurtarma amacında ortaklaşan bir özellik taşır (Mardin, 2017a: 17). Abdülhamid ise Osmanlı'nın Müslüman nüfustan güç alarak ayakta kalabileceğini düşünmüştür (Bora, 2018: 34). Bu amacı gerçekçi kılmak için dışarıda güç dengesini gözetirken içeride çeşitli reformlarla devleti güçlendirmeye çalışmıştır: "Askeri aygıtı modernleştirmek, siyasi yapıda ıslahata gitmek, vilayet yönetimlerini ve kamu idaresini yeniden yapılandırmak, istatistiki araçları geliştirmek, adliyenin işleyişini iyileştirmek, ticaretin ve tarımın gelişmesi için gerekli tedbirleri almak, büyük bayındırlık çalışmalarına girişmek, eğitimi geliştirmek" (Georgeon, 2006: 279). Ayrıca bu dönemde gerçekleştirilen reformların diğer dönemlerden farklı olarak İngiltere ve Fransa yerine, uluslararası konjonktürün etkisiyle Almanya modelinde ilerlediği görülmektedir. On sekizinci yüzyılda Fransa, on dokuzuncu yüzyılda İngiltere modernleşmenin esin kaynağı olurken, 1890 yılından 1918'e kadar Almanya tarzı modernleşme etkili olmuştur (Parla, 2009: 23).

II. Abdülhamid döneminde planlanan reformlar Tanzimat dönemi reformlarıyla birlikte düşünüldüğünde, yirminci yüzyılda meydana gelen rejim değişikliğinin ve kurulan modern devletin temellerinin on dokuzuncu yüzyılda atıldığı görülmektedir. Özelikle bu dönem eğitim alanında yapılan reformlar sonucunda açılan okullarda eğitim gören Müslüman nüfusun yirminci yüzyılda rejim değişikliğini sağlayacak nesilleri yetiştirmesi, Abdülhamid'in kendi mezar kazıcılarını kendisinin ortaya çıkarmasıyla sonuçlanmıştır (Ahmad, 2006: 127). Bu noktada yapılan eğitim reformlarının mahiyetine değinmekte fayda var. Osmanlı'da eğitimi modernleştirme çabaları kapsamında açılan okullar, geleneksel anlamda medreselerin kapatılması anlamına gelmemiştir. Ulema ve medrese dişında örgütlenen ve laik eğitim veren okullar bürokratik sınıfı yetiştirirken, laik okullarda yetişen öğrenciler giderek devlet yönetimine hâkim olmaya başlamış ve bu sayede 1908 yılı itibariyle ilmiye sınıfının devlet üzerindeki etkisi en aza indirilmiştir (Ortaylı, 2018: 190). Böylece düalist yapı, eğitim alanında da kendini göstermiş modern ve geleneksel okullar bir arada olmaya devam etmiştir. Eğitim reformlarında temel sorun, birinci düzey sıbyan mekteplerinin ihmal edilmesidir. 1869'da çıkarılan Maarif-i Umumiye Nizamname'si ile eğitim sistemi sıbyan okulu-rüştiye ve sultani olmak üzere düzenlenmiş olsa dahi Ortaylı'nın dikkat çektiği üzere devlet ilk öğretim alanında mali sorumluk almamış, devlete hizmet edecek memur veya teknisyenlerin yetişmesi için yükseköğrenime özen göstermiştir (Ortaylı, 2018: 194). Bu durum eğitim alanındaki reformların dahi pragmatik bir bakış açısıyla ele alındığını göstermesi açısından 
önemlidir. Böylece Tanzimat döneminde başlatılan eğitimde modernleşme çabaları Abdülhamid döneminde devam etmiş, Tanzimat’ta çoğunlukla İstanbul'da açılan okullar Abdülhamid döneminde imparatorluğun diğer bölgelerinde açılmaya başlamıştır (Baktıaya, 2017: 153). Dolayısıyla okul sayısı ve okullaşmanın artması açılarından niceliksel olarak büyük bir artışın görüldüğü ve eğitimin kurumsallaştığı en önemli evre II. Abdülhamid dönemidir. Resmi ideoloji ve resmi tarih, Abdülhamid'in kendi iktidarını -mutlak monarşiyi- yeniden üretmesini sağlayacak bir unsur olarak bu dönemde inşa edilmiş ve sonraya miras kalmıştır. "Ulema” ve "medresenin" sistem dişına itilerek, ideolojik bir aygıt olarak dinselleşmenin enjekte edildiği ve aynı zamanda bilimsel gelişmeye önem veren eğitim politikaları, Abdülhamid'in sadık tebaa yetiştirme amacını barındırır. Ancak, Abdülhamid iktidarının ilk on yılında uygulanan Tanzimat mirası pozitivist eğitim politikaları, sultana bağlı vatandaş tipinin oluşmasına engel olmuş ve Abdülhamid'in kendi okullarından yetişen kuşak onu yerinden etmiştir (Alkan, 2008: 33-35). Dönemin eğitim politikalarına paralel olarak resmi dilin Osmanlı Türkçesi olarak belirlenmesi, bürokratik yapıyı oluşturan kesimin çoğunluğunun Türk kökenli olmasına neden olmuş ve bu durum idari açıdan Osmanlıcılık idealine uyumsuzluk gösteren temel bir çelişkiyi beraberinde getirmiştir. İdarenin modernleşmesi, sistemin de merkezileşmesini gerektirmiş ancak dil sorunu idari görevlerdeki Osmanlı Türkçesi bilenlerle sınırlamıştır. Her ne kadar Türk olmayan kişilerin merkezi sisteme dahil edilmesi için eğitim aracılığıyla dil sorununun önüne geçilmeye çalışılsa da uygulamada Türk olmayanların sisteme dahil olması zorlaşmış ve merkezin yerel karşısındaki gücünü sağlamlaşmaya devam etmiştir (Abu-Manneh, 2016: 131).

Abdülhamid döneminin genel yapısına tekrar dönecek olursak, Tanıl Bora Abdülhamid'in yaptığını modern ulus devletin subasmanını inşa etmek, formatını oluşturmak olarak değerlendirir. Ona göre, İslamiyet bu dönemde modern milliyetçiliğe göre şekillendirilirken aynı şekilde milliyetçiliğin ve topyekûn modernleşmenin adımları da bu dönemde atılmıştır (Bora, 2018: 34). Böylece aydınlanmacı despotizmin uygulandığı Abdülhamid dönemi modernleşmesi Tanzimat modernleşmesi kadar etkili bir süreç olarak değerlendirilir. Reformlar, paradokslarını içinde barındırırken modern devletin milliyetçi kimliği bu dönemde şekillenmeye başlamıştır. Yine bu dönemde, Yeni Osmanlılara nazaran daha kurumsallaşmış bir muhalif hareket sahneye çıkmıştır: Jön Türkler. Abdülhamid yönetiminin ana muhaliflerinden biri olarak beliren Jön Türkler, çoğunluğu yukarıda bahsedilen modern laik okullarda eğitim görmüş öğrencilerdir. Çeşitli fraksiyonlara ayrılmış olan Jön Türk hareketi içerisinden bir grup Tıbbiyeli öğrenci 1889'da anayasal ve meşruti yönetimi geri getirmek 
amacıyla İttihad-ı Osmanlı'yı kurarak Osmanlı'nın ilk örgütlü muhalefetini oluşturmuşlardır (Zürcher, 2000: 112). 1895 sonrası İttihat ve Terakki Cemiyeti olarak anılan örgüt, 1908 Devrimi'ni gerçekleşmesinde, II. Meşrutiyet'in ilanında ve Abdülhamid döneminin sonlanmasında etkin rol üstlenmişlerdir.

Bu noktada Jön Türklerin genel mahiyetine kısaca bakmakta fayda bulunmaktadır. Selefleri olan Yeni Osmanlıların mirasçı olarak kabul edilen Jön Türkler, Yeni Osmanlılar gibi “vatanı kurtarmak” amacıyla bir araya gelen Osmanlı aydınlarıdır. Jön Türkler hareketi içerisindeki isimlerin çoğunluğu Tıbbiyeli, Mülkiyeli ve Harbiyeli öğrenciler, yönetici sınıf mensupları, mektepliler ve burjuva zihniyetlilerdir (Akşin, 2017: 132). Farklı kesimlerden insanların bir araya getiren "vatanı kurtarma" ortak hedefi, hareketin ideolojik yelpazesini genişletmektedir. Jön Türkler içerisinde liberal, muhafazakâr, pozitivist fikirlere sahip isimler bulunmaktadır. Hareketin heterojen yapısı, tek merkezden tek bir fikir akımı çerçevesinde gelişen bir hareket olmadığını göstermektedir. Mizancı Murat, Ahmet Rıza, Abdullah Cevdet ve Prens Sabahattin gibi farklı fikir akımlarının savunucuları Jön Türk hareketinin önemli isimlerinden bazılarıdır. Bu isimleri bir araya getiren itki ise vatanı kurtarmak için meşruti yönetime geri dönülmesi gerektiğini savunmalarıdır. Böylece anayasal meşrutiyete geri dönülmesi talebi Abdülhamid muhaliflerinin ortak paydasını oluşturmuş ve onları bu amaç etrafında bir araya getirmiştir. Hanioğlu, anayasal yönetim talebinin nedeni olarak, o dönem için modern devletin ölçütü olarak anayasallaşma ve yönetim mekanizmasında parlamentonun varlığının önem arz ettiğine dikkat çeker ve Jön Türklerin meşrutiyeti modernleşmek için kıstas aldıklarını belirtir (Hanioğlu, tarih yok: 70).

Bununla birlikte, uğruna 1908 devriminin yapıldığı Kanun-i Esasi, 19081918 döneminde Osmanlı yönetiminin modernleşme çabalarına bir sınır çizecektir. Berkes, Kanun-i Esasi'de devletin dininin İslam olarak belirlenmiş olmasını 1908 sonrası yaşanan siyasal bunalımın başlıca nedeni olarak görür ve devlet din ayrımını amaç edinen yeni bir anayasanın geliştirilememiş olmasını eleştirir (Berkes, 2019: 430). Ahmad ise var olan kapitülasyonların, 1914 yılında kaldırıldığı tarihe kadar 1908 sonrası hedeflenen reformlara engel teşkil ettiğini ve modern bağımsız devlet kavramının oluşmasını engellediğini belirtir (Ahmad, 2006: 149). Hem Berkes'in hem de Ahmad'in dikkat çektiği hususlar haricinde hatırda tutulması gereken şey, 1908 sonrası yönetimin kendinden önceki yüzyılın iç sorunlarını devralması ve yirminci yüzyılla birlikte hızlanan sömürge faaliyetlerinin Osmanlı üzerinde daha yoğun bir dış baskı oluşturmasıdır. Böylece iç ve dış faktörler, reformların sınırlanmasında etkili olmuştur. 
Aykut Kansu 1908 Devrimi adlı çalışmasında, 1908 devrimini geç kalmış liberal bir devrim olarak tanımlar (Kansu, 2009: 358). Tebaadan yurttaşa geçişin, tüm azınlıkların eşit bir şekilde birinci sınıf vatandaş olarak tanınmasının, herkesin aynı hukuk düzenine tabi kılınmasının sağlanmasının bu dönemde mümkün olduğunu belirten Kansu, özgürlükçü modern yönetim arayışı içerisinde cumhuriyet fikrinin de bu dönem tartışıldığına ve daha önemlisi hedeflendiğine dikkat çeker $(2009,363)$. Önceki dönem modern devletin temel kıstası olarak görülen meşruti monarşi fikri yerini cumhuriyet fikrine bırakırken, yönetim şekline bakış açısındaki bu değişim dönemin kendinden önceki dönemlerden temel farklılığını oluşturmuştur. Tanzimat dönemi en radikal düşünürlerin bile doğrudan dile getirmeye çekindiği, varlığının sorgulanmadığı saltanat artık tartışılabilen bir konu haline gelmiştir.

Sina Akşin, 1908-1913 dönemini “denetleme iktidarı” olarak tanımlamaktadır (Akşin, 2017: 369). Her ne kadar 1909'da yaşanan gelişmeler liberallere ve muhafazakarlara karşı İttihatçıların iktidarını sağlamlaştırmış (Ahmad, 2006: 144) olsa da 1913'de iktidarını tam olarak sağlayana kadar, İttihat ve Terakki gibi devrimci bir parti dahi büyük dönüşümleri gerçekleştirememiştir (Akşin, 2017: 369). Akşin aynı çalışmasında denetleme iktidarının devrimci olarak adlandırılabilecek atılımları olarak sarayın rolünün kısıtlanmasını, siyaset ve düşünce ortamının özgürleşmesini, emperyalizmin kısıtlamalarına rağmen ticaret ve sanayi alanındaki iktisadi dönüşümleri (devlet eliyle kalkınma) ve eğitimde gerçekleştirilen yenilikleri sayar (Akşin, 2017: 170178). Özellikle ekonomi alanında 1908 - 1918 yılları arasında uygulanan milli iktisat politikası Osmanlı'da yerli burjuva sınıfını oluşturmayı ve böylece kapitalist bir sisteme geçişi hedeflemektedir. Ancak burada, yine içine düşülen hatayı Ahmad, Berkes'den aktararak şu şekilde tarif eder (Ahmad, 2008: 58): “İttihatçılar kendi ekonomik sorunlarını sanki Türkiye'de bu sistem dahilmiş gibi, kapitalist ekonomi kategorilerine göre ele alıyorlar." Hilmi Ziya Ülken ise ikinci meşrutiyet dönemindeki özgür düşünce ortamının etkisiyle, Tanzimat'tan beri var olan İslamcı-Batıcı ayrımının yanı sıra, ilk izlerine Yeni Osmanlıların fikirlerinde rastlanan Türkçülüğün eklenmesiyle bu üç ideolojinin savunucularının birbirleriyle fikri anlamda çatıştıklarını söyler (Ülken, 2019: 279). Bununla birlikte, Türkçülüğün siyasal bir akım olarak Türk ulusçuluğuna dönüşmesi İttihat ve Terakki'yle mümkün olurken, Yusuf Akçura, Ahmet Ağaoğlu, Ziya Gökalp gibi düşünürler aracılığıyla 1905’ten sonra gelişen ve Cumhuriyet'e miras bırakılan bir ideoloji olduğunu belirtmek gerekir (Akşin, 2017: 385).

Özetle, on dokuzuncu yüzyıl Osmanlı modernleşmesine II. Mahmud, Ali ve Fuad Paşalar ile II. Abdülhamid gibi önemli isimlerin reform anlayışı 
damgasını vurmuş, modernleşme genel olarak Batılılaşmak fikri etrafında ve Batı tarzı modern kurumları tesis etmek doğrultusunda gerçekleşmiştir. Yirminci yüzyıl Osmanlı modernleşmesi ise İttihat ve Terakki önderliğinde, devlet eliyle liberal bir yönetim anlayışıyla gerçekleştirilmeye çalışılmış ancak kendinden önceki yüzyılın çelişkilerini içerisinde barındırmaya devam etmiştir. İttihat ve Terakki'nin modernleşme yöntemlerine içeriden olduğu kadar emperyalist devletlerden de tepki gelirken, Balkan Savaşları ve Birinci Dünya Harbi zorunlu tedbirlerin alınmasını ve savaş ekonomisine geçişi "zorunlu” kılmıştır. Bütün bunlarla birlikte, Osmanlı modernleşmesi Cumhuriyet modernleşmesinin alt yapısını fikri ve siyasal alanlarda oluştururken, modernleşmenin temel hedefi olan "vatanı kurtarmak" konusunda başarılı olunamamış, ekonomik yıkımı beraberinde getiren uzun bir dünya savaşının sonunda Osmanlı İmparatorluğu son bulmuştur.

\section{Sonuç}

Modernleşme, belirli bir mekânda ve belirli bir tarihsel dönemde ortaya çıkan ekonomik, siyasal ve toplumsal dönüşümü ifade eder. On sekizinci yüzyılda Batı Avrupa'da yaşanan bu sürecin karakteristik özelliği, üretim tarzının kapitalistleşmesi nedeniyle geleneksel toplumdan sanayi toplumuna geçişin arkasında bir itici gücün varlığı yani burjuvazi sınıfının gelişmesi ve sahneye çıkmasıdır. Burjuvazinin gelişmesi ve iktidarı ele geçirmesi ile parçalanmış toplumsal ve kültürel prekapitalist ögeler, yeni ekonomik yapı ile bütünleştirilmiş ve merkezileştirilmiştir.

On dokuzuncu yüzyılla birlikte Batı Avrupa'nın modernleşmesinden farklı olarak gelişen Osmanlı-Türk modernleşmesi, Türkiye sosyal bilimler literatüründe birçok yazar tarafından farklı perspektiflerden ele alınmış bir konudur. Literatürün bu denli geniş olması, konunun yeniden yazılması açısından bazı handikapları içinde barındırmaktadır. Handikaplarıyla birlikte Osmanlı modernleşmesi hakkında yazmak, konunun yeni araştırmacıları için cazipliğini korumaktadır. 1970’lere kadar davranışçı gelenek ve modernleşme kuramı çoğunlukla kullanılan kuram olurken sonraki on yıllarda farklı yaklaşımlara göre yazılan çalışmaların sayısı artmıştır. Hem imparatorluğun son yüzyıllarını hem de erken Cumhuriyet dönemini doğru anlamak için modernleşme sürecinin genel çerçevesini çizmek önem arz etmektedir.

Osmanlı'da reformlar Batı etkisinde gerçekleşse de modernleşme Batı'dan oldukça farklı bir görünüme sahiptir. On dokuzuncu yüzyıl, Osmanlı İmparatorluğu'nun tarihsel seyrinin farklılaştığı, önceki yüzyılın kısıtlı ve yüzeysel reform hareketlerinin yerini daha bütünsel reformlara bıraktığı, geleneksel 
kurumsal yapının yerini, Batı'yla uyumlu bir modern devletin almaya başladığı dönemdir. Sürüp giden askeri yenilgiler ve toprak kayıpları Batı tarzı reformalar yapılmasını kaçınılmaz hale getirirken, Osmanlı modernleşmenin kesintisiz bir şekilde devam ettiğini iddia etmek mümkün değildir. Doğrusal bir gelişmeden ziyade devamlı dönüşen bir özellik taşıyan on dokuzuncu yüzyıl modernleşmesi, dinamiklerini kendi köklerinde barındırır. Bu açıdan Osmanlı modernleşmesi çok boyutlu ve çok zamanlı düşünülmesi gereken kendine özgü bir süreçtir. Nerede başlayıp nerede biteceği ya da nasıl uygulanacağı net olmayan reformlar, bürokratlar ve devlet yöneticileri eliyle toplumsal bir talebe karşılık olarak değil pragmatik bir zorunluluğun ürünü olarak gerçekleştirilmiştir. Bu durum geleneksel olan ile modern olanın bir arada bulunduğu ikili bir yapı oluşturmuş, modernleşme elitist ve halk tarafından içselleştirilmeyen bir özellik sergilemiştir. Devleti kurtarmak amacı etrafında şekillenen Osmanlı modernleşmesinin savunucuları ve yöntemsel karşıtları, süreç içerisinde beliren sorunların nereden kaynaklandığını tespit etmekte zorlanmış; tespit ettiği sorunlara yönelik çözüm önerileri getirme konusunda da seçmeci davranmıştır. Projenin amorf tarafı, buradan kaynaklanmaktadır. On dokuzuncu yüzyıl modernleşmesinin diğer bir özelliği Tanzimat'a kadar bütünlüklü bir plan yerine ağırlıklı olarak askeri ve eğitim alanlarındaki yenileşme gayesi etrafında sürdürülmüş olmasıdır. Modernleşme Tanzimat'la birlikte siyasal, kültürel ve toplumsal yenilik çabalarını içererek kurumsallaşmıştır. Ancak Tanzimat dönemi reformları da önceki dönem reformları gibi kişiye bağlı görünümünü sürdürmüştür. Padişah veya paşalar özelinde gerçekleşen reformlar, padişah veya paşanın değişmesiyle birlikte kesintiye uğramıştır. On dokuzuncu yüzyılda iktidarı ele geçiren kişi(ler), reform yapma konusunda hem fikir olsa da haleflerin, seleflerin projeleri yerine kendi projelerini uygulama çabası reformları süreksiz, kişiye bağlı ve kopuk hale getirmiştir. Tanzimat reformları kültürel ve toplumsal yenilikleri amaçlasa da bu dönemde yeni bir toplum yaratma fikrinin olmadığı iddia edilebilir. Yukarıdan aşağı ya da tepeden modernleşme şeklinde adlandırılan Osmanlı modernleşmesi, Tanzimat döneminde de yukarıdan aşağı bir formda devam etmiş, topluma yeniliklere uyum sağlama rolü yüklense de reformların olumlu bir toplumsal bir karşılığı öngörüldüğü ölçüude gerçekleşmemiştir. Bu noktada devlet-toplum ile devlet-birey ilişkisinin tek taraflı geliştiği ve devletin sorumluluk yükleyici olarak topluma pasif bir rol verdiğini söylemek mümkündür. Vatandaşlık kavramı devlete karşı görev ve yükümlülükten ibaret sayılmıştır. Toplumun pasif bir noktada konumlandırılması Batı'da toplumsal değişim taleplerinin taşıyıcısı olan burjuva ve aydın sınıfının Osmanlı'da zayıf ve sayıcı yetersizliğinin bir yansıması olarak 
belirirken, Osmanlı toplumunda modernleşmenin herhangi bir aşamasında tabandan bir taleple değişim gözlemlenmemiş, bu özellik erken Cumhuriyet döneminde de devam etmiştir.

Tanzimat dönemi gelişen ve imparatorluğun sonuna kadar etkili olan muhalif hareketler, temel hedef konusunda hem fikir olmakla birlikte modernleşmeye bakış açıları farklılık göstermiştir. Batı'nın üstünlüğü ve Batı modeli reformların yapılması gerekliliği taraflar tarafından kabul edilirken, toplumun kültürel değerlerinin korunarak Batı'nın sadece bilimsel ve teknik yeniliklerin aktarılmasını savunanlar ile topyekûn bir Batılılaşmayı savunanlar arası çatışma imparatorluğun sonuna kadar devam etmiştir. Kaçınılmaz bir ilerlemenin tarihsel ürünü olmak yerine pragmatist çizgide ilerleyen Osmanlı modernleşmesi, çeşitli dönemlerde Osmanlıcılık, İslamcılık ve Türkçülük fikri akımları etkisi altında kalmış, Batılılaşma isteği üç fikrin temsilcileri tarafından farklı düzeylerde gereklilik olarak ele alınmıştır. Abdülhamid dönemi, İslamcl, pragmatist ve muhafazakâr bir görünüme sahipken, II. Meşrutiyet dönemi pragmatist çizgiyi devam ettirerek önceki döneme göre Türkçülüğün daha tartışılır olduğu bir dönem olmuştur. 1908 sonrası dönemde, diğer dönemlerden ayıran temel tartışma ise artık yönetim şeklinin de tartışılır hale gelmesi ve Cumhuriyet savunucularının bu dönemde ortaya çıkmasıdır.

Deneyimi Cumhuriyet'e devrolan modernleşme hikayesi, yeni dönemde radikalleşerek toplumsal ve kültürel alanın dönüşümünü bütünüyle kapsayacak biçime bürünmüştür. Sonuç olarak Osmanlı'nın geç dönem reformları, modern ulus-devletin ortaya çıkabileceği koşulları hazırlamış ve yenileşme hareketlerini devam ettirebilecek askeri ve sivil bürokratik sınıfı oluşturmuştur. Yani Osmanlı'nın ilk modernleşecek alan olarak gördüğü askeri kurumlar, Cumhuriyet'in kurulmasında toplumu modernleştirecek aktörler olmuştur. Bu bakımdan, on dokuzunu yüzyıl Osmanlı modernleşmesi deneyimi, kendinden sonraya çelişkileriyle birlikte belli bir birikim bırakmıştır. Devletin çöküşüne karşı bir çözüm olarak görülen modernleşmeyi görece 1 lımlı biçimde uygulayan Osmanlı'ya karşılık, genç Cumhuriyet ise modernleşmeyi "muasır medeniyetler seviyesine ulaşma" amacı içeren radikal kurucu paradigmaya dönüştürmüştür. 


\section{Kaynakça}

Abu-Manneh, Butrus, (2016), “Arap-Osmanlıcılarının Jön Türk Devrimi'ne Tepkileri”, Yuval Ben- Bassat ve Eyal Ginio (ed.), Jön Türklerin Filistin’i, İstanbul: Koç Üniversitesi Yayınları, ss. 127-142.

Ahmad, Feroz (2006), Bir Kimlik Peşinde Türkiye, İstanbul: İstanbul Bilgi Üniversitesi Yayınları.

Ahmad, Feroz (2008), Modern Türkiye'nin Oluşumu, İstanbul: Kaynak Yayınları.

Akşin, Sina (2017), Jön Türkler ve Ittihat ve Terakki, Ankara: İmge Kitapevi.

Akyıldız, Ali (2012), Osmanlı Bürokrasisi ve Modernleşme, İstanbul: İletişim Yayınları.

Alkan, Mehmet (2008), “Osmanlı İmparatorluğu'nda Modernleşme ve Eğitim”, Türkiye Araştırmaları Literatür Dergisi, Sayı: 12, ss. 9-84.

Aydın, Mehmet Akif (2003), “Mecelle-i Ahkam-ı Adliyye”, İslam Ansiklopedisi, c. 28, Ankara: TDV Yayınları.

Baktıaya, Adil (2017), Osmanlı Suriye’sinde Arapçılığın Doğuşu: Sosyo-Ekonomik Değişim ve Siyasal Düşünce, İstanbul: İletişim Yayınları.

Bauman, Zygmunt (2000), Modernlik ve Müphemlik, İstanbul: Ayrıntı Yayınları.

Belge, Murat (2012), Militarist Modernleşme: Almanya, Japonya, Türkiye, İstanbul: İletişim Yayınları.

Berkes, Niyazi (2019), Türkiye’de Çağdaşlaşma, İstanbul: Yapı Kredi Yayınları.

Bora, Tanıl (2018), Cereyanlar: Türkiye’de Siyasal İdeolojiler, İstanbul: İletişim Yayınları.

Çadırcı, Musa (1999), «Tanzimat», Osmanlı Ansiklopedisi, Cilt 6, Ankara: Yeni Türkiye Yayınları.

Davison, Roderic H. (2005), Osmanlı Imparatorluğunda Reform: 1856-1857, İstanbul: Agora Kitaplığı.

Demirel, Tanel (2019), Türk Siyasetini Anlamak: Yaklaşımlar Hakkında Bir Deneme, Ankara: Liberte Yayınları.

Deringil, Selim (2014), İktidarın Sembolleri ve İdeoloji: II. Abdülhamid Dönemi (1876-1909), İstanbul: Doğan Kitap.

Doğan, Özlem (2002), “Türkiye'de Pozitivizm ve Siyaset”, Uygar Kocabaşoğlu (ed.), Modern Türkiye'de Siyasi Düşünce: Modernleşme ve Batıcılık, Cilt 3, İstanbul: İletişim Yayınları, ss. 452-465.

Georgeon, François (2006), Sultan Abdülhamid, İstanbul: Homer Kitabevi .

Giddens, Anthony (1994), Modernliğin Sonuçları, İstanbul: Ayrıntı Yayınları.

Göçek, Fatma Müge (1999), Burjuvazinin Yükselişi, İmparatorluğun Çöküşü: Osmanlı Batılılaşması ve Toplumsal Değişme, Ankara: Ayraç Yayınevi.

Hanioğlu, Şükrü (tarih yok). Bir Siyasal Örgüt Olarak Osmanlı: Itttihad ve Terakki Cemiyeti ve Jön Türklük (1889-1902), İstanbul: İletişim Yayınları.

Heper, Metin (2018), Türkiye’de Devlet Geleneği, Ankara: DoğuBatı Yayınları.

Kansu, Aykut (2009), 1908 Devrimi, İstanbul: İletişim Yayınları.

Keyder, Çağlar (2014), Türkiye'de Devlet ve Sınıflar, İstanbul: İletişim Yayınları.

Koçak, Cemil (2009), “Yeni Osmanlılar ve Birinci Meşrutiyet”, Tanıl Bora ve Murat Gültekin (ed.), Modern Türkiye'de Siyasal Düşünce, Cumhuriyet'e Devreden Düşünce Mirası: Tanzimat ve Meşrutiyet’in Birikimi, Cilt 1, İstanbul: İletişim Yayınları, ss. 72-83. 
Habermas, Jürgen (1994), “Modernlik: Tamamlanmamış Bir Proje”, Necmi Zeka (ed.), Postmodernizm, İstanbul: Kıyı Yayınları, ss. 31-44.

Lewis, Bernard (2008), Modern Türkiye'nin Doğuşu, Ankara: Arkadaş Yayınevi.

Mardin, Şerif (2017a), Jön Türklerin Siyasi Fikirleri, İstanbul: İletişim Yayınları.

Mardin, Şerif (2017b), Yeni Osmanlı Düşüncesinin Doğuşu, İstanbul: İletişim Yayınları.

Mardin, Şerif (2018), Türk Modernleşmesi, İstanbul: İletişim Yayınları.

Oktay, Cemil (2007), Siyaset Bilimi İncelemeleri, İstanbul: Alfa Yayınları.

Ortaylı, İlber (1995), “Osmanlı Devleti’nde Laiklik Hareketleri Üzerine”, Ersin Kalaycıoğlu ve Ali Yaşar Sarıbay (ed.), Türkiye’de Siyaset: Süreklilik ve Değişim, İstanbul: Der Yayınları, ss. $173-184$

Ortaylı, İlber (2018), Imparatorluğun En Uzun Yüzyıll, İstanbul: Kronik Kitap.

Osmanağaoğlu Karahasanoğlu, Cihan (2011), “Mecelle-i Ahkam-ı Adliyye’nin Yürürlüğe Girişi ve Türk Hukuk Tarihi Bakımından Önemi”, Ankara Üniversitesi Osmanlı Tarih Araştırma ve Uygulama Merkezi Dergisi, Sayı: 29, ss. 93-124.

Outwaite, William (2008), Modern Toplumsal Düşünce Sözlüğü, İstanbul: Illetişim Yayınları.

Pamuk, Şevket, (2007), Osmanlı-Türkiye Iktisadi Tarihi, İstanbul: Iletişim Yayınları.

Parla, Taha (2009), Ziya Gökalp, Kemalizm, Türkiye'de Korporatizm, İstanbul: Deniz Yayınları.

Toker, Nilgün ve Tekin, Serdar (2007), “Batıcı Siyasi Düşüncenin Karakteristikleri ve Evreleri: ‘Kamusuz Cumhuriyet'ten ‘Kamusuz Demokrasi'ye”, Tanıl Bora ve Murat Gültekin (ed.), Modern Türkiye'de Siyasi Düşünce: Modernleşme ve Batıcılık, Cilt 3, İstanbul: Illetişim Yayınları, ss. 82-87.

Ülken, Hilmi Ziya (2019), Türkiye'de Çağdaş Düşünce Tarihi, İstanbul: Türkiye İş Bankası Kültür Yayınları.

Yeşil, Fatih (2016), ihtilaller Çağında Osmanlı Ordusu: Osmanlı Imparatorluğuıunda Sosyoekonomik ve Sosyopolitik Değişim Üzerine Bir İnceleme (1793-1826), İstanbul: Tarih Vakfı Yurt Yayınları.

Swingewood, Alan (1998), Sosyolojik Düşüncenin Kısa Tarihi, Ankara: Bilim ve Sanat Yayınları.

Zürcher, Erik Jan (2006), Modernleşen Türkiye'nin Tarihi, İstanbul: İletişim Yayınları. 